\title{
Innovative Floor Truss Top Chord for Achieving Long Spans
}

\begin{abstract}
S. V. T. J. Perera
Abstract: Steel and concrete composite systems are generally used as major structural components in multi-storey buildings. Composite construction in buildings is more popular with steel decking since it serves as a working platform to support the construction loads and also as permanent formwork for concrete. To achieve large column free spans (in the range of $8 \mathrm{~m}-12 \mathrm{~m}$ ), as often demanded for multistorey office buildings, "steel and concrete composite floor trusses" may form economical solutions since they provide the facility to accommodate various service ducts within the structural zone. The concept of introducing a concrete filled steel tube (CFST), instead of the conventional open flanged steel section, as the top chord of these floor trusses has been discussed. However, the viability of this new concept should be ensured by experimental evidence on the longitudinal shear transfer capacity at the composite stage.
\end{abstract}

This paper discusses the experimental results of a series of push-off tests conducted on CFST embedded composite slab panels. The effect of providing different concrete top cover and effect of different concrete strength have been investigated, and the results are compared with existing practice related to headed shear studs.

Keywords: composite slab, steel, concrete, concrete filled steel tubes, steel decking, longitudinal shear

\subsection{Introduction}

\subsection{Background}

Composite construction using steel and concrete has been used since the early 1920s. It gained widespread use in bridges in the 1950s and in building in the 1960s in the world. The reason for that is structural designers have been aware of the advantages of composite construction, such as saving of steel, reduction of overall structural depth, and the increase in floor stiffness and load capacity.

Composite construction in buildings has become more popular with the profiled steel sheeting since it serves as a working platform to support the construction loads and permanent formwork for the concrete. This eliminates the need for traditional, temporary forms and falsework. Also the sheets are suitably shaped to ensure proper bond with the concrete, the sheeting can provide all or part of the main tension reinforcement in the slab.

Steel and concrete composite systems are generally used as major structural components in multi-storey buildings. Therefore structural arrangement of "floors" is particularly important. Several different configurations of composite floor systems are in use worldwide for long spans, namely, composite stub-girders, slim floor systems, composite trusses, composite beams with web openings in the steel beam, etc.

A "composite truss" is a steel truss, the top chord of which is designed to act compositely with a concrete slab right above it. To achieve large column free span (in the range of $8 \mathrm{~m}$ $12 \mathrm{~m}$ ), as often demanded for multy-storey office buildings, "steel concrete composite trusses" may form an economical solution since they provide the facility to accommodate various service ducts within the structural zone (i.e. these could be passed through the openings in the truss) which would otherwise have to be placed underneath it.

In this type of construction, the bare steel truss is generally expected to withstand the construction stage loads until the composite action develops in the top chord when the concrete is hardened. Consequently the size of the steel top chord member is governed by the construction stage loading (non-composite action). This means the composite truss contains

Eng. S.V.T.J. Perera, B.Sc. Eng. (Hons) (Moratuwa), AMIE (SL) Resident Engineer, STRAD Consultants (Pvt)Ltd, Premier Pacific Topaz (Pvt) Ltd. 
more than adequate amount of structural steel fixed to its top chord for the serviceability and ultimate design states. An economical design may hence be achieved by introducing alternative means for the truss top chord, which is to reduce structural steel. Instead of the conventional open flanged steel section, as the top chord of these floor trusses, one such alternative is to use a concrete filled steel tube, as described in this study.

The use of hollow steel tubes filled with concrete has become wide spread in the past few decades. This is mainly due to their properties such as high strength, high ductility, and large energy absorption capacity. In this type of composite trusses the uncertainty is with the shear connection than its compressive strength capacity as a top chord of the truss. The viability of this concept could be ensured by experimental evidence on the longitudinal shear carrying capacity at the composite stage.

In conventional composite beams, shear carrying capacity is gained by mechanical connectors (to resist specially longitudinal shear), the most popular form being welded headed studs. The shear studs are welded to the flange of the steel beam, generally through a composite steel deck. A composite slab is cast on top of the deck with the stud, functioning to tie the slab and beam together as unit. A composite beam has greater strength and stiffness than if the beam and slab were behaving independently. In concrete filled steel tube (CFST) embedded composite trusses which is suited in this study, the shear carrying capacity is gained by surface ared of concretesteel contact.

Strength prediction equations have predominantly been derived from empirical studies. Both push-off (push-out) tests, which were first used in Switzerland in the 1930s [1], and full-scale beam tests have been used to develop shear stud strength prediction expressions. Because of the large size and expense of beam tests, push-off tests are usually used to evaluate a wide array of parameters. A push-off test specimen is shown in Figure 1. Beam tests are often used to verify the results of methods developed from push-off tests. It has been found that push-off test results can be used to accurately predict beam test rasults if the push-off tests are detailed similar to the beam test [2].

\subsection{Longitudinal Shear Failure}

The longitudinal shear force in composite beams is transferred across the steel flange/concrete interface at a discrete number of points, by the dowel action of the individual shear connectors. If the concrete slab fails to resist the longitudinal shear stresses produced by connectors, longitudinal cracking along the line of the beam may occur. This leads to a loss of interaction between the steel beam and the concrete compression flange, and a drastic reduction in the moment capacity of the composite section [3].

\subsection{Push-Off Test}

The most common way used to evaluate the shear connector strength and the behavior is the push-off test. Push-off tests have been used as early as the 1930s and were used to predict the strength of studs in solid slabs as described above.

The property of a shear connector of most relevance to design is the relationship between the shear force transmitted and, the corresponding slip at the interface. This loadslip curve should ideally be found from tests on full-scale composite beams, but in practice a simpler "push-off specimen" is used (see Figure 1). Failure mode of shear connectors in composite slabs could also be found from the push-off tests.

\subsection{Objectives}

To design composite trusses with CFSTs in top chords, further experimental evidence is required on the shear carrying capacity at the composite stage. Two configurations using $114 \mathrm{~mm}$ diameter pipes, as the truss top chord were proposed for this study.

a) In configuration 1, the top chord was an embedded concrete filled steel tube (CFST) in composite slab and in composite slab it acts as a continuous circular shear connector.

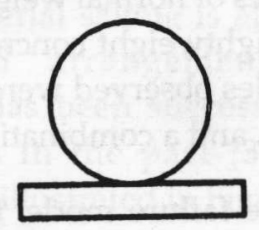


b) In configuration 2, headed shear studs were used as shear connector and top chord of composite slab was a CFST but it was not embedded to slab.

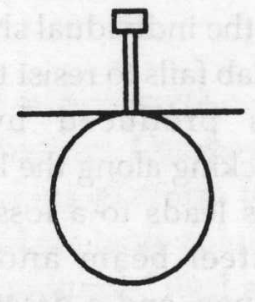

The proposal was for testing of specimens of the two configurations by varying the clear-cover thickness in the concrete and the concrete grade since effect of those were not well knowit. The project objectives are as described below.

- To experimentally verify feasibility of the configuration suitable for top chord members of composite trusses

- To determine the effect of concrete top cover on shear transfer capacity of new deck slab configurations.

- To determine the effect of compressive strength of concrete, on shear transfer capacity of new deck slab configurations.

- To identify the pattern of shear failure planes for each of new deck slab configurations.

\subsection{Literature Review}

This review will begin with the strength prediction equations developed for welded headed studs in solid slabs and will include more recent research on welded headed studs in slabs with formed metal deck.

Ollgaard et al [4] performed 48 solid slab pushoff tests. Variables considered were concrete compressive strength, concrete splitting tensile strength, modulus of elasticity of coricrete, density of concrete, stud diameter and type of aggregate. The stud tensile strength, slab reinforcement, and geometry were constant for all tests. Stud diameters tested were $5 / 8 \mathrm{i} .2$, and $3 / 4$ in. Two types of normal weight concrete and three types of lightweight concrete were tested. The failure modes observed were stud shearing, concrete failure, and a combination of the two.

For the concrete failure mode, the lightweight concrete had more and larger cracks in the slabs than did the normal weight concrete. When one pair of connectors was in each slab, all failed by shearing off the studs. The lightweight concrete tended to crush in front of the studs, causing the stud to remain straight when it deformed. When lightweight concrete was used, stud strengths decreased $15 \%$ to $25 \%$.

The normal weight concrete provided greater restraint of the stud, so more curvature of the stud occurred. Studs in both types of concrete rotated a large amount at the weld. The tests showed that studs in both types of concrete exhibited considerable inelastic deformation before failure as the specimens did not fail suddenly at ultimate load.

The tests showed that the stud strength decreases when the concrete strength decreases considerably. The data indicated that the stud strength is more influenced by the concrete compressive strength and modulus of elasticity than by the concrete splitting tensile strength and density. They also concluded that the concrete properties control at ultimate load, so shear connector tensile strength is not as critical; however, smaller diameter connectors would be more dependent on stud tensile strength, because the concrete forces would not be as great.

Elkelish and Robinson [5] studied six parameters that affect longitudinal cracking of composite beams with metal deck using experimental specimens as well as a finite element analysis. The parameters investigated were type of loading, concrete compressive strength, beam span-to-slab width ratio, thickness of the solid part of the slab, percentage of transverse reinforcement, and the existence of the metal deck. Three loading conditions were used: uniformly distributed load, single point load at mid-span, and two point loads at the third points.

The results showed that a uniformly distributed load causes the longitudinal crack to start at the top of the slab; single point load and two point loads cause the crack to start at the bottom. The initial longitudinal crack is delayed with an increase of the span-to-width ratio, the steel beam yield strength-to-concrete strength ratio, the thickness of the solid part of the slab, and the transverse reinforcement ratio. Welded wire mesh did not increase the resistance to initial longitudinal cracking. The metal deck helps to 
resist cracking when point loads are applied, but it does not help for a slab that is uniformly loaded.

Oehlers and Coughlan [6] analyzed 116 push-off tests to derive the shear stiffness of shear stud connections in composite beams. The authors stated that the flexibility of the shear connection is important because it indirectly affects the flexural strength and fatigue life of the beam. The tests showed that studs in strong concrete are stiffer than studs in weaker concrete.

In almost all of the tests, surface cracks appeared along with separation of the concrete from the deck just before ultimate load was reached. After ultimate load, the slabs were seen to ride over the sheeting and cause extensive profile distortion. Wedge-shaped failure cones, not pyramidal-shaped cones as suggested by Hawkins and Mitchell [7], occurred around the studs in all of the tests. This mechanism has been found to occur in a composite beam test.

The connection resistance $\left(Q_{K}\right)$ can then be found as

$\mathrm{Q}_{\mathrm{K}}=\mathrm{K} \lambda\left(\mathrm{A}_{\mathrm{c}} \sqrt{\mathrm{cu}} \mathrm{f}_{\mathrm{c}}\right)$

Where, $\quad \mathrm{f}_{\mathrm{cu}}=$ concrete strength

$\mathrm{A}_{\mathrm{c}}=$ area of concrete

$\mathrm{K}=$ shear friction factor

$\lambda=$ factor for concrete type

Sublett et al [8] performed 36 push-out tests to determine the strength of studs in composite open web steel joists. Test parameters were base member thickness, deck rib geometry, slab thickness, stud position, and normal load application. The authors concluded that strength of concrete highly influences the stud ultimate strength: higher strength concrete may increase stud ultimate strength, and lower strength concrete may decrease stud ultimate strength. The stud strength may be assumed to vary approximately linearly with base member thickness.

Shear connectors can be classified as ductile or non-ductile. Ductile connectors are those with sufficient deformation capacity to justify the simplifying assumption of plastic behaviour of the shear connection in the structure considered. Shear-slip curves are obtained by push-off tests. Figure 2.1 shows examples of both ductile and non-ductile behaviour. A ductile connector has an elastic-plastic type of curve with a yield plateau corresponding to the connector characteristic resistance $P_{R k}$ and to a high ultimate slip capacity $s_{u^{\prime}}$. Eurocode 4 considers that connectors having a characteristic slip capacity higher or equal to $6 \mathrm{~mm}$ can be assumed to be ductile, provided that the degree of shear connection is sufficient for the spans of the beam being considered.

In brief, Conventional headed shear connectors' shear carrying capacity increase with concrete grade and concrete top cover. Therefore, in this study different concrete grade and concrete top cover were used to find out shear carrying capacity with two new configurations.

\subsection{Methodology}

\subsection{General}

In Sri Lankan construction industry practical concrete grades with slabs are grade 20 and 30 . The economical concrete top covers are $20 \mathrm{~mm}$ and $25 \mathrm{~mm}$. Therefore, for each configuration $\mathrm{C} 20, \mathrm{C} 30$, and $\mathrm{C} 45$ concrete were used with concrete top cover $25 \mathrm{~mm}$ to check the effect of concrete grade on shear transfer capacity. Similarly concrete top cover $20 \mathrm{~mm}, 25 \mathrm{~mm}$, and $30 \mathrm{~mm}$ were used with $\mathrm{C} 30$ concrete to check effect of concrete top cover on shear transfer capacity. In each case used three replicates were tested to verify the results. All together forty five samples were tested for all three configurations and effect of configuration on shear transfer capacity also checked.

The proposed "push-off test (push test)" has a single span arrangement with only one deck slab specimen, as opposed to "standard push-off tests" described in Standard Codes of Practice [9] [10] for conventional composite arrangements where two identical deck slab specimens to be fixed on either side of the main steel beam. The major reason for that is the proposed configurations are not containing open flange steel beam sections. A considerable amount of material saving is also expected by the proposed arrangement. A similar arrangement has been successfully used for push off tests in the past [3]. The testing arrangement is illustrated in Figure 3.1.

The proposed single span push off test rig provides additional means of maintaining 
verticality of the deck slab specimens during loading, as shown in Fig. 3.1(b).

\subsection{Test Specimens}

\subsubsection{Configuration 1}

In this configuration shear transfer capacity of composite slab relies on contact between steel tube and concrete. In other words friction force between steel and concrete enhances the shear transfer capacity of composite slab in configuration 1 which is different from conventional headed shear studs in configuration 2.

All push off slab specimens were constructed using wooden forms. Each specimen consisted of concrete filled steel tubes, each of which was welded to a $200 \mathrm{~mm}$ wide $\times 950 \mathrm{~mm}$ long $\times 9 \mathrm{~mm}$ thick steel plate. Two " $\mathrm{S}$ " shape flashings $(25 \mathrm{~mm}$ $\times 50 \mathrm{~mm} \times 20 \mathrm{~mm}$ ) riveted to two steel profile sheets, were riveted to steel plate as shown in Figure 3.2(a).

The concrete filled steel tube was welded to steel plate prior to concrete filling. Then it was filled by concrete and concrete test cubes were cast at the same time. Concrete test cubes were placed without curing (to check behaviour of compressive strength of concrete, in sida the steel tube), but with proper covering.

Two layers of steel reinforcement (R6@200c/c) were placed top of the steel tube. Mortar cover blocks were used to support the reinforcement. Silicon was applied to fill the openings. All slabs were cast horizontally. After the concrete was placed in the forms, it was vibrated with a mechanical vibrator.

The specimens were covered and moist-cured for seven days, at which time the forms were removed. Concrete test cubes were cast along with the specimens and cured similarly.

The push-off specimens were tested 28 days after being cast. At that time both concrete test cube samples were tested.

\subsubsection{Configuration 2}

In this configuration conventional headed shear studs ( $19 \mathrm{~mm}$ dia., $80 \mathrm{~mm}$ height) were used to improve the shear transfer capacity of composite slab (see Figure 3.2(b)).

\subsection{Testing Procedure}

The load was first applied in increments up to $40 \%$ of the expected failure load and then cycled 25 times between $5 \%$ and $40 \%$ of expected failure load. Subsequent load increments were then imposed such that failure did not occur in less than 15 minutes. The longitudinal slip between each concrete slab and concrete filled steel tube was measured continuously during loading or at each load increment. As close as possible to each group of connectors, the transverse separation between the steel section and each slab was measured.

\subsection{Experimental results}

All push-off test results in each configuration are presented in Table 4.1, and 4.2 with average concrete cube strength of four samples. In each configuration concrete cube strength, and concrete top cover were used as variables.

During the analysis, mean value of each variable was considered and outliers were neglected.

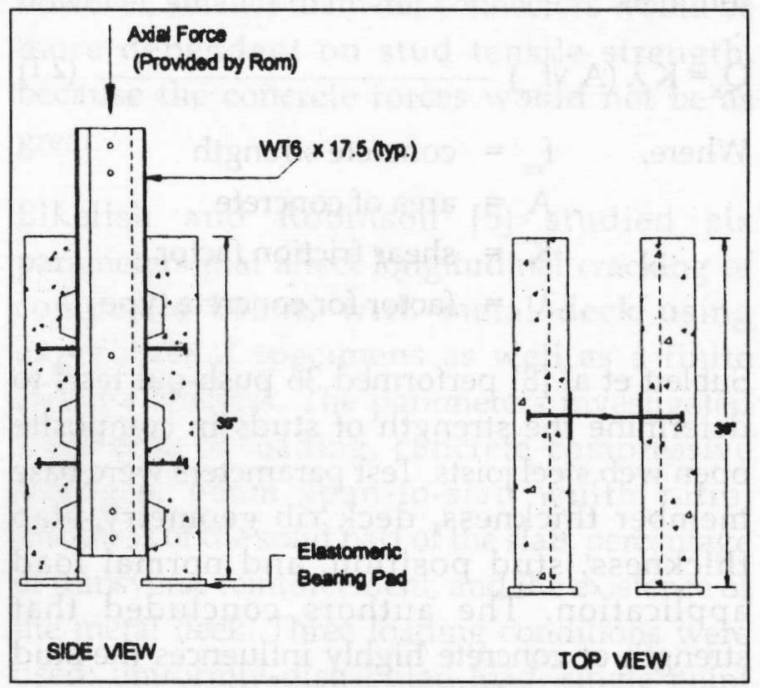

Figure 1: Typical Details of Push-Off Specimen

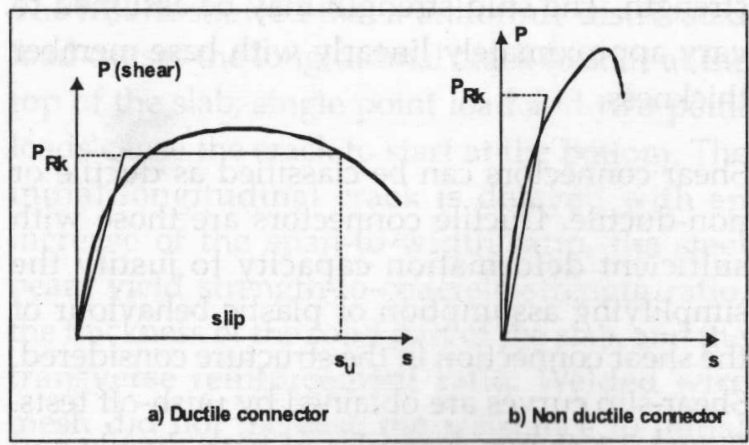

Figure 2.1: Standard connection behavior 


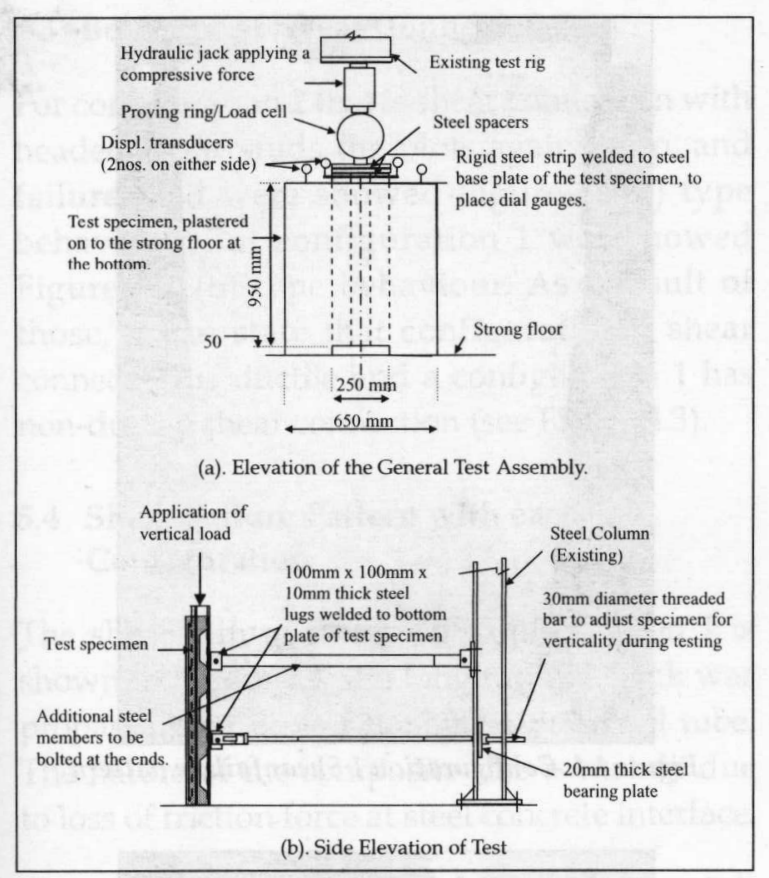

Figure 3.1: Testing Arrangement

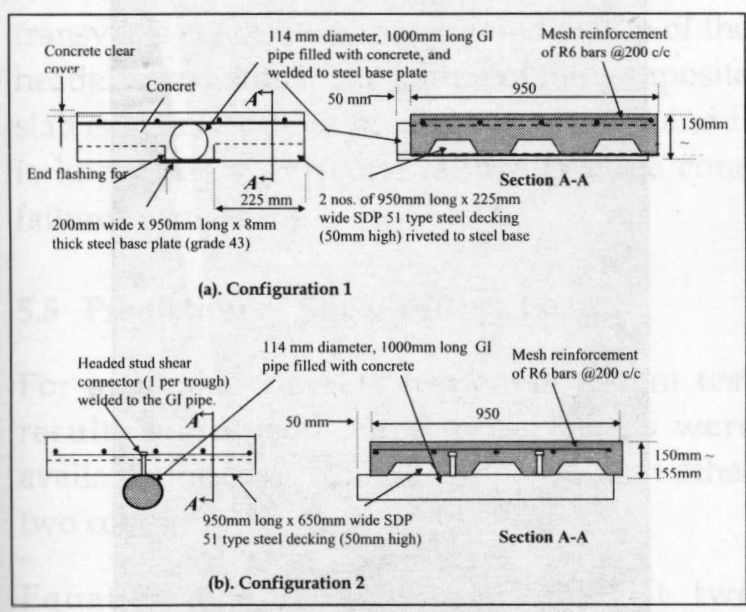

Figure 3.2: Different Configurations of Deck-Slab Specimens to be Tested.

Table 4.1: Configuration 1 test results

\begin{tabular}{|c|c|c|c|c|}
\hline Specimen & $\begin{array}{c}\text { Design } \\
\text { concrete } \\
\text { strength } \\
\left(\mathrm{Nmm}^{-2}\right)\end{array}$ & $\begin{array}{c}\text { Concrete } \\
\text { top cover } \\
(\mathrm{mm})\end{array}$ & $\begin{array}{l}\text { Concrete } \\
\text { cube } \\
\text { strength } \\
\left(\mathrm{Nmm}^{-2}\right)\end{array}$ & $\begin{array}{c}\text { Failure } \\
\text { load } \\
(\mathrm{kN})\end{array}$ \\
\hline \multirow{3}{*}{$\begin{array}{l}\text { C30-20-1-i } \\
\text { C30-20-1-ii } \\
\text { C30-20-1-iii }\end{array}$} & \multirow{3}{*}{30} & \multirow{3}{*}{20} & 36.4 & 501 \\
\hline & & & 33.6 & 501 \\
\hline & & & 38.2 & 496 \\
\hline \multirow{3}{*}{$\begin{array}{l}\text { C30-25-1-i } \\
\text { C30-25-1-ii } \\
\text { C30-25-1-iii }\end{array}$} & \multirow{3}{*}{30} & \multirow{3}{*}{25} & 34.5 & 569 \\
\hline & & & 35.3 & 589 \\
\hline & & & 26.8 & 517 \\
\hline \multirow{3}{*}{$\begin{array}{l}\text { C30-30-1-i } \\
\text { C30-30-1-ii } \\
\text { C30-30-1-iii }\end{array}$} & \multirow{3}{*}{30} & \multirow{3}{*}{30} & 25.3 & 444 \\
\hline & & & 32.3 & 527 \\
\hline & & & 41.7 & 678 \\
\hline \multirow{3}{*}{$\begin{array}{l}\text { C20-25-1-i } \\
\text { C20-25-1-ii } \\
\text { C20-25-1-iii }\end{array}$} & \multirow{3}{*}{20} & \multirow{3}{*}{25} & 32 & 501 \\
\hline & & & 32.2 & 428 \\
\hline & & & 30.8 & 574 \\
\hline \multirow{3}{*}{$\begin{array}{l}\text { C45-25-1-i } \\
\text { C45-25-1-ii } \\
\text { C45-25-1-iii }\end{array}$} & \multirow{3}{*}{45} & \multirow{3}{*}{25} & 45.1 & 772 \\
\hline & & & 48.3 & 933 \\
\hline & & & 48.2 & 678 \\
\hline
\end{tabular}

Table 4.2: Configuration 2 test results

\begin{tabular}{|c|c|c|c|c|}
\hline Specimen & $\begin{array}{c}\text { Design } \\
\text { concrete } \\
\text { strength } \\
\left(\mathrm{Nmm}^{-2}\right)\end{array}$ & $\begin{array}{c}\text { Concrete } \\
\text { top cover } \\
(\mathrm{mm})\end{array}$ & $\begin{array}{l}\text { Concrete } \\
\text { cube } \\
\text { strength } \\
\left(\mathrm{Nmm}^{-2}\right)\end{array}$ & $\begin{array}{c}\text { Failure } \\
\text { load (kN) } \\
\text { (One stud } \\
\text { per rib) }\end{array}$ \\
\hline \multirow{3}{*}{$\begin{array}{l}\text { C30-20-3-i } \\
\text { C30-20-3-ii } \\
\text { C30-20-3-iii }\end{array}$} & \multirow{3}{*}{30} & \multirow{3}{*}{20} & 40 & 121.2 \\
\hline & & & 39.8 & 121.2 \\
\hline & & & 36.9 & 128.3 \\
\hline \multirow{3}{*}{$\begin{array}{l}\text { C30-25-3-i } \\
\text { C30-25-3-ii } \\
\text { C30-25-3-iii }\end{array}$} & \multirow{3}{*}{30} & \multirow{3}{*}{25} & 44.3 & 151.1 \\
\hline & & & 37.8 & 131.2 \\
\hline & & & 39.2 & 149.6 \\
\hline \multirow{3}{*}{$\begin{array}{l}\text { C30-30-3-i } \\
\text { C30-30-3-ii } \\
\text { C30-30-3-iii }\end{array}$} & \multirow{3}{*}{30} & \multirow{3}{*}{30} & 32.8 & 135.4 \\
\hline & & & 38.6 & 156.7 \\
\hline & & & 36.4 & 155.3 \\
\hline \multirow{3}{*}{$\begin{array}{l}\text { C20-25-3-i } \\
\text { C20-25-3-ii } \\
\text { C20-25-3-iii }\end{array}$} & \multirow{3}{*}{20} & \multirow{3}{*}{25} & 27.5 & 149.6 \\
\hline & & & 25 & 125.5 \\
\hline & & & 31.1 & 168.1 \\
\hline \multirow{3}{*}{$\begin{array}{l}\text { C45-25-3-i } \\
\text { C45-25-3-ii } \\
\text { C45-25-3-iii }\end{array}$} & \multirow{3}{*}{45} & \multirow{3}{*}{25} & 51.7 & 192.2 \\
\hline & & & 51.1 & 168.1 \\
\hline & & & 49.8 & 192.2 \\
\hline
\end{tabular}

Table 4.3: Effect of concrete strength on failure load on Configuration-1 (for concrete top cover $25 \mathrm{~mm}$, with average test results)

\begin{tabular}{|c|c|c|}
\hline $\begin{array}{c}\text { Specimen } \\
\text { group }\end{array}$ & $\begin{array}{c}\text { Concrete } \\
\text { cube strength } \\
\text { (Nmm-2) }\end{array}$ & $\begin{array}{c}\text { Failure } \\
\text { load (kN) }\end{array}$ \\
\hline C20-25-1 & 31 & 501 \\
C30-25-1 & 35 & 579 \\
C45-25-1 & 47 & 725 \\
\hline
\end{tabular}

Table 4.4: Effect of concrete strength on failure load on Configuration-2 (for concrete top cover $25 \mathrm{~mm}$, with average test results)

\begin{tabular}{|c|c|c|}
\hline $\begin{array}{c}\text { Specimen } \\
\text { group }\end{array}$ & $\begin{array}{c}\text { Concrete } \\
\text { cube strength } \\
\text { (Nmm-2) }\end{array}$ & $\begin{array}{c}\text { Failure load } \\
(\mathbf{k N}) \text {, for single } \\
\text { two studs }\end{array}$ \\
\hline C20-25-3 & 28 & 138 \\
C30-25-3 & 40 & 144 \\
C45-25-3 & 51 & 184 \\
\hline
\end{tabular}

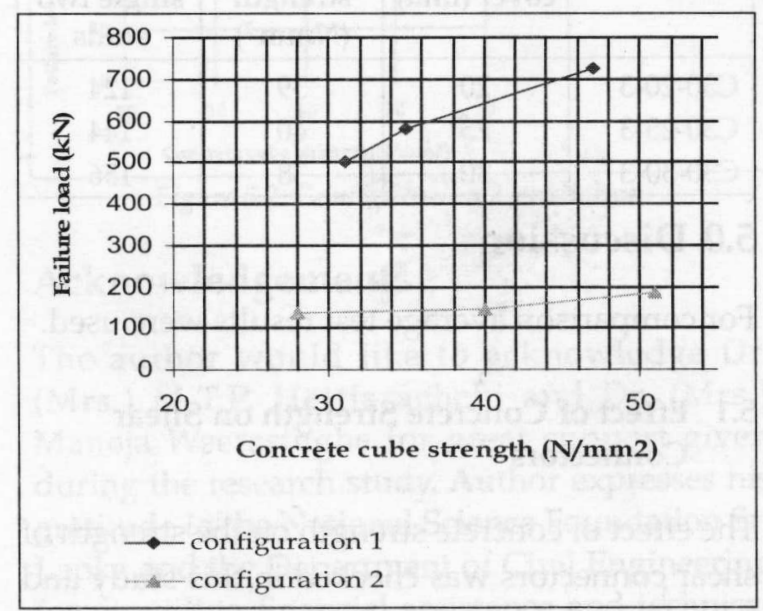

Figure 4.1: Effect of concrete strength on failure load on different configurations 
Table 4.5: Effect of concrete top cover on failure load on Configuration-1 (for grade 30 concrete, with average test results)

\begin{tabular}{|c|c|c|c|}
\hline $\begin{array}{c}\text { Specimen } \\
\text { group }\end{array}$ & $\begin{array}{c}\text { Concrete } \\
\text { top } \\
\text { cover (mm) }\end{array}$ & $\begin{array}{c}\text { Concrete } \\
\text { cube } \\
\text { strength } \\
\text { (Nmm-2) }\end{array}$ & $\begin{array}{c}\text { Failure load } \\
\text { (kN) }\end{array}$ \\
\hline C30-20-1 & 20 & 36 & 499 \\
C30-25-1 & 25 & 35 & 579 \\
C30-30-1 & 30 & 37 & 602 \\
\hline
\end{tabular}

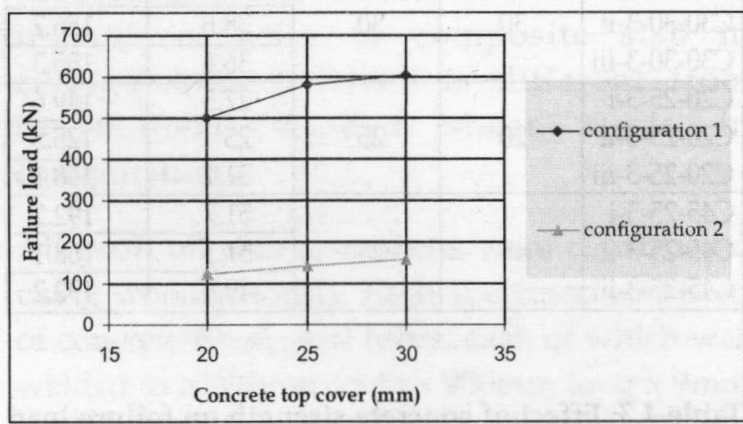

Figure 4.2: Effect of concrete top cover on failure load on different configurations

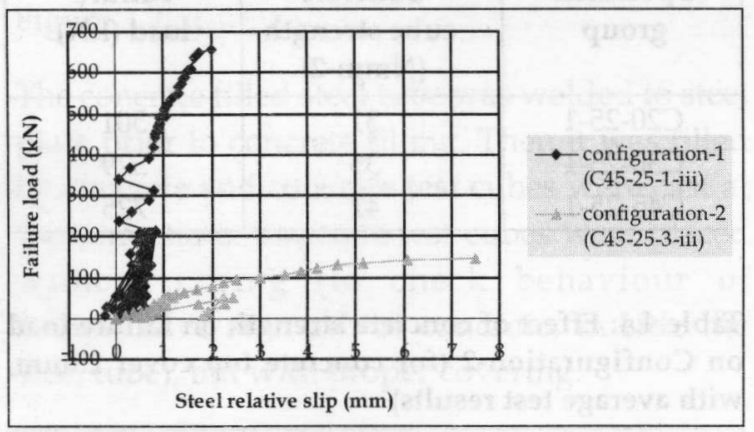

Figure 4.3: Experimental connection behaviour

Table 4.6: Effect of concrete top cover on failure load on Configuration-2 (for grade 30 concrete, with average test results)

\begin{tabular}{|c|c|c|c|}
\hline $\begin{array}{c}\text { Specimen } \\
\text { group }\end{array}$ & $\begin{array}{c}\text { Concrete } \\
\text { top } \\
\text { cover (mm) }\end{array}$ & $\begin{array}{c}\text { Concrete } \\
\text { cube } \\
\text { strength } \\
\text { (Nmm-2) }^{-2}\end{array}$ & $\begin{array}{c}\text { Failure load } \\
\text { (kN), for } \\
\text { single two } \\
\text { studs }\end{array}$ \\
\hline C30-20-3 & 20 & 39 & 124 \\
C30-25-3 & 25 & 40 & 144 \\
C30-30-3 & 30 & 38 & 156 \\
\hline
\end{tabular}

\subsection{Discussion}

For comparison average test results were used.

\subsection{Effect of Concrete Strength on Shear Connectors}

The effect of concrete strength on the strength of shear connectors was checked in this study and it was checked for configuration 1 , and 2 as shown in Table 4.3, 4.4 and Figure 4.1.

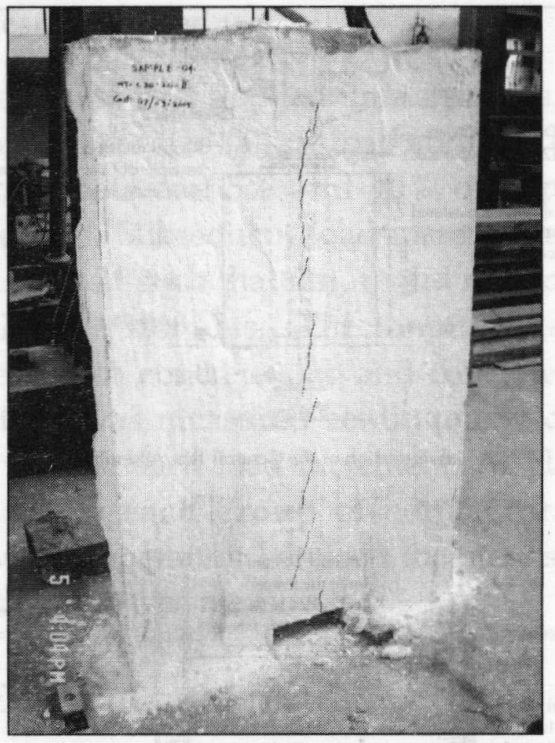

Figure 4.4: Configuration 1 Shear failure pattern

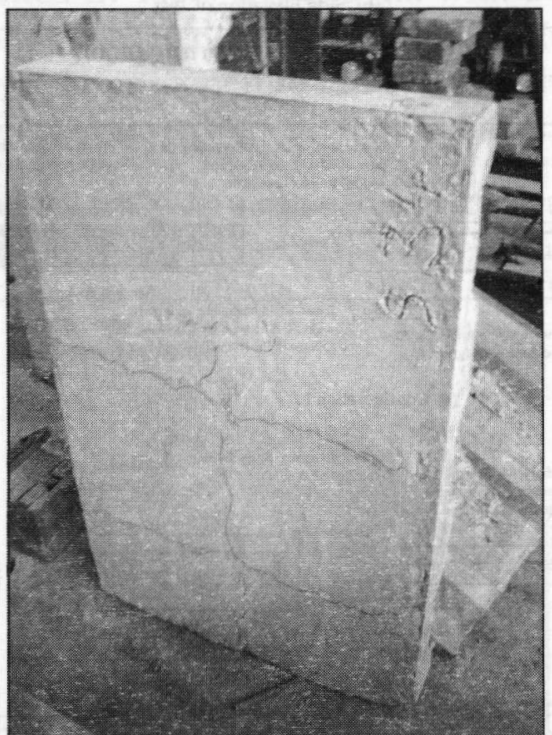

Figure 4.5: Configuration 2 Shear failure pattern

With configuration 1 and 2 the failure load increased $16 \%$ to $45 \%$ and $4 \%$ to $33 \%$ with increase of concrete strength respectively. Configuration 1 shear carrying capacity was nearly four times the configuration 2 capacity.

\subsection{Effect of Concrete Top Cover on Shear Connectors}

The effect of concrete top cover on the strength of shear connectors was checked in this study and it was checked for configuration 1 , and 2 as shown in Table 4.5, 4.6 and Figure 4.2.

With configuration 1 and 2 the failure load increased $16 \%$ to $21 \%$ and $16 \%$ to $26 \%$ with increase of concrete top cover respectively. Configuration 1 shear carrying capacity was nearly four times the configuration 2 capacity. 


\subsection{Behavior of Shear Connector}

For configuration 2 that is shear connection with headed shear studs the plots against slip, and failure load were showed Figure 2.1(a) type behaviour. But configuration 1 was showed Figure 2.1 (b) type behaviour. As a result of those, it can state that configuration 2 shear connection is ductile and a configuration 1 has non-ductile shear connection (see Figure 4.3).

\subsection{Shear Failure Pattern with each Configuration}

The shear failure pattern of configuration 1 is shown in Figure 4.4; the longitudinal crack was propagated on top of the embedded steel tube. The failure of the composite slab is mainly due to loss of friction force at steel concrete interface.

The shear failure pattern of configuration 2 is shown in Figure 4.5, longitudinal crack, and transverse cracks were propagated on top of the headed shear studs. The failure of the composite slab is mainly due to pulling out of stud, and it is known as shear cone failure (Wedge cone failures were seen).

\subsection{Prediction of Shear Failure Load}

For analysis, concrete top cover $25 \mathrm{~mm}$ test results were used since more results were available for cover $25 \mathrm{~mm}$ compared with other two covers.

Equation 2.1 was modified to suit two configurations. Concrete area for configuration 1 was taken as surface area of steel tube $331,414 \mathrm{~mm}^{2}$ and for configuration 2 it was taken as wedge shear cone area $227,334 \mathrm{~mm}^{2}[11,12]$.

$\mathrm{Q}_{\mathrm{K}}=\left(\mathrm{A}_{\mathrm{c}} \mathrm{V}_{\mathrm{cu}}\right)^{\mathrm{n}}$

Where, $\mathrm{n}=0.44$ for Configuration 1

$\mathrm{n}=0.36$ for Configuration 2

Prediction failure load was compared with experimental failure load as shown in Figure 5.1, and 5.2.

\subsection{Conclusions}

Configuration 1 and 2 shear carrying capacity increase with concrete cube strength and concrete top cover. The shear carrying capacity of configuration 1 is nearly cour times configuration 2 capacity.

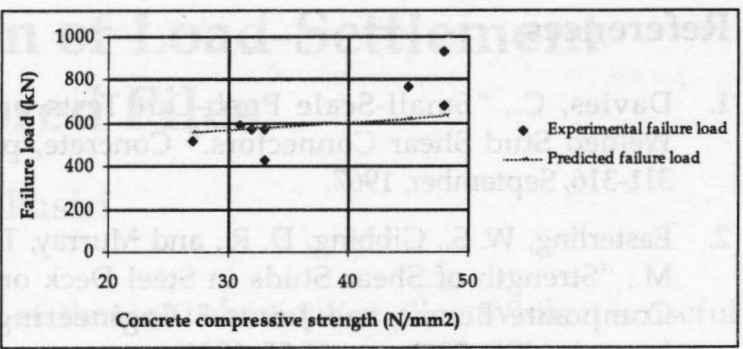

Figure 5.1: Configuration 1 prediction

With configuration $1,16 \%-45 \%$ of increase in shear carrying capacity was achieved by increasing concrete cube strength from grade 20 to grade 45 . Also $16 \%$ - $21 \%$ of increase in shear carrying capacity was achieved by increasing concrete top cover from $20 \mathrm{~mm}$ to $30 \mathrm{~mm}$.

With configuration 2, 4\%-33\% of increase in shear carrying capacity was achieved by increasing concrete cube strength from grade 20 to grade 45 . Also $16 \%$ - $26 \%$ of increase in shear carrying capacity was achieved by increasing concrete top cover from $20 \mathrm{~mm}$ to $30 \mathrm{~mm}$.

The connector type for configuration 1 was non ductile and it was ductile with configuration 2 .

The shear failure pattern propagated at minimum top cover at configuration 1 . One longitudinal crack was seen at top of the steel tube in configuration 1, and Shear cone failure was seen with configuration 2 .

Therefore Configuration 1 is more suitable for composite floor truss top chord compared with configuration 2 .

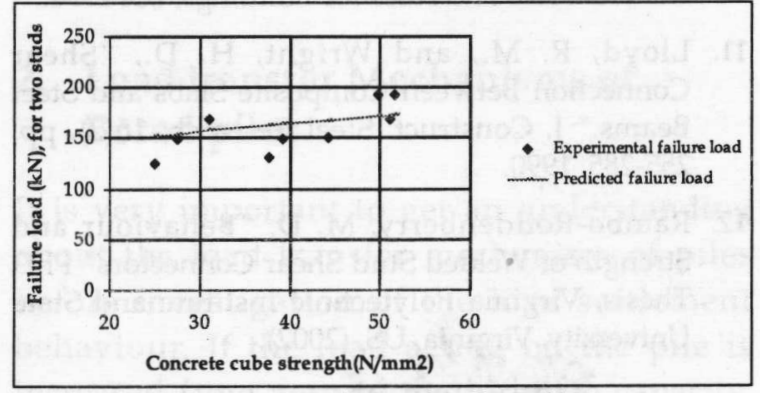

Figure 5.2: Configuration 2 prediction

\section{Acknowledgements}

The author would like to acknowledge Dr. (Mrs.) M.T.P. Hettiarachchi and Dr. (Mrs.) Manoja Weerasinghe for great support given during the research study. Author expresses his gratitude to the National Science Foundation Sri Lanka and the Department of Civil Engineering for providing financial assistance and technical support during the post graduate program. 


\section{References}

1. Davies, C., "Small-Scale Push-Out Tests on Welded Stud Shear Connectors." Concrete, p. 311-316, September, 1967.

2. Easterling, W. S., Gibbing, D. R., and Murray, T. M., "Strength of Shear Studs in Steel Deck on Composite Beams and Joints." Engineering Journal, AISC, 30(2), , p. 44-55, 1993.

3. Hicks, S. J., Mconnel, R. E.. "Investigation of Longitudinal Splitting of Composite Structures." PhD Thesis, Cambridge University, UK (1995)

4. Ollgaard, J. G., Slutter, R. G., and Fisher, J. W., "Shear Strength of Stud Connectors in Lightweight and Normal-Weight Concrete." Engineering Journal, AISC, 8(2), pp. 55-64, 1971.

5. Elkelish, M. S., and Robinson, H., "Longitudinal Cracking of Composite Beams with Ribbed Metal Deck." Can. J. Civ. Eng., 13(5), pp. 733-740, 1986.

6. Oehlers, D. J., and Coughlan, C. G., "The Shear Stiffness of Stud Shear Connections in Composite Beams." J. Constr. Steel Res., 6, pp.273-284, 1986.

7. Hawkins, N. M., and Mitchell D., "Seismic Response of Composite Shear Connections." J. Struct. Engrg., ASCE, 110(9), pp. 2120-2136, 1984.

8. Sublett, C. N., Easterling, W. S. and Murray, T. M. "Strength of Welded Headed Studs in Ribbed Metal Deck on Composite Joists." Report No. CE/VPI-ST 92-03. Virginia Polytechnic Institute and State University, Blacksburg, VA, (1992).

9. BS 5950 : The structural use of steelwork in building; Part 4: Code of practice for design of composite slabs with profiled steel sheeting, BSI 1994.

10. DD ENV 1994-1-1: Eurocode 4: Design of composite steel and concrete structures; Part 1-1: General rules and rules for buildings, BSI 1994.

11. Lloyd, R. M., and Wright, H. D., "Shear Connection Between Composite Slabs and Steel Beams." J. Construct. Steel Research, 15(2), pp. 255-285, 1990

12. Rambo-Roddenberry, M. D. "Behaviour and Strength of Welded Stud Shear Connectors" PhD Thesis, Virginia Polytechnic Institute and State University, Virginia, US, (2002). 